\title{
Propolis Protective Role Against Morphological, Hormonal Biochemical and Histological Alterations Induced by Sildenafil Overdoses
}

\author{
Rol Protector del Propóleo contra las Alteraciones Morfológicas, Hormonales, \\ Bioquímicas e Histológicas Inducidas por Sobredosis de Sildenafil
}

\author{
Mansour Almansour*; Yazun Jarrar** \& Bashir Jarrar****
}

\begin{abstract}
ALMANSOUR, M.; JARRAR, Y. \& JARRAR, B. Propolis protective role against morphological, hormonal biochemical and histological alterations induced by Sildenafil overdoses. Int. J. Morphol., 34(2):533-540, 2016.

SUMMARY: Sildenafil is widely used for the treatment of erectile dysfunction with few studies are available on the protective role of propolis against its reproductive toxicity. The present study aims to investigate the hormonal biochemical and histomorphometric alterations induced in the testicular tissues by sildenafil overdoses. Four groups of rabbits were exposed to sildenafil with or without propolis as follows: Group I received the formulated vehicle, Group II received sildenafil (3 mg/kg), Group III received propolis (50 mg/ $\mathrm{kg}$ ), Group IV received sildenafil plus propolis. Sildenafil lowered body weight gain, testosterone and follicular stimulating hormone concentration but increased testis index while luteinizing hormone was almost not affected. Moreover, sildenafil treated rabbits showed degenerative seminiferous tubules and disturbance of spermatogenesis together with spermatocytes sloughing and nuclear alterations. Exposure to sildenafil plus propolis ameliorated tubular alterations, spermatogenesis disturbances, hormonal levels changes and partially protected spermatocytes from morphological nuclear alterations but could not ameliorate the effect on the body weight gain and testis index. The findings of the present work may indicate that propolis can ameliorate partially the reproductive toxicity induced by sildenafil overdoses with more need for further studies on the adverse effect of these doses on the other vital organs.
\end{abstract}

KEY WORDS: Propolis; Sildenafil; Testis; Histological alterations; Toxicity.

\section{INTRODUCTION}

Sildenafil is one of the most frequently prescribed drugs worldwide for the treatment of erectile dysfunction (Boolell et al., 1996). It acts by releasing of nitric oxide from the penile nerve ending leading to the relaxation of corpus cavernosum smooth muscles (Schultheiss et al., 1997). Sildenafil can ameliorate erectile dysfunction in elderly men, but had a lower efficacy rate with increasing age (Muller et al., 2007). Moreover, this drug showed an efficacy in treatment of pulmonary hypertension in children and in patients with hemoglobinopathies that lead to severe pulmonary hypertension (Huddleston et al., 2009). Some studies have provided promising evidences that sildenafil can be used as tolerated treatment option for benign prostatic hyperplasia (Wang et al., 2010). In addition, some investigations showed that sildenafil attenuated renal injury in cisplatin-induced nephrotoxicity, increased antinociception of morphine and inhibited carbonic anhydrase activity in red blood cells (Abdülkadir Coban et al., 2009). Other reports indicated that sildenafil modulated spontaneous $\mathrm{Ca}^{2+}$ waves in corpus cavernosum, induced deliberate hypotension and elevated total serum testosterone (Sergeant et al., 2009). Case reports showed that hearing impairment, nose bleeding together with nose stuffiness were presented after sildenafil introduction (Krenzelok, 2000). In addition, sildenafil overdose might be fatal due to its arrhythmogenic potential (Tracqui et al., 2002). On the other hand, sildenafil decreased histological alteration in the myocardial cells in hypertensive-rat models and reduced pulmonary fibrosis (Oruc et al. 2010). Moreover, sildenafil was found to augment the histopathological effects of amlodipine and to alter the ultrastructure of interstitial endocrine cell (Leydig cells) (Saraiva et al., 2009).

\footnotetext{
* Department of Zoology, College of Science, King Saud University, Riyadh, Saudi Arabia.

** Pharmacy Department, Faculty of Pharmacy, Al-Zaytoonah University of Jordan, Amman, Jordan.

*** Department of Biological Sciences, College of Science, Jerash University, Jerash, Jordan.
} 
Propolis is a natural product derived from plant resins collected by honeybees (Khalil, 2006). This crude is used in cosmetics, food supplement and in medicine for centuries in various health disorders. Uses of propolis include treatment of the cardiovascular systems, respiratory system, dental care, treatment and prevention of cancer, immune system support, digestive tract disorder, liver protection and many others (Urgur \& Arslan, 2004). In addition, propolis helps tissue regeneration, strengthening of capillaries and has anti-diabetic activity while dermatological and cosmetic applications at this time are probably the most common uses for this natural crude and its extracts (Lejeune et al., 1988). Some studies showed that propolis could protect the renal tissues from damage induced by chemicals and environmental toxicants (El-Mazoudy et al., 2011; Yousef et al., 2010). Moreover, this natural product ameliorated the ilium injury and hepatorenal histological alterations induced by methotrexate treatment (Yousef \& Salama, 2009; Badr et al., 2011).

To the best knowledge of the authors, few studies are available on the reproductive toxicity of sildenafil associated with the hormonal changes and the testicular histological alterations induced by this drug. With this objective, the present study aims to evaluate the protective role of propolis against reproductive toxicity of sildenafil overdoses.

\section{MATERIAL AND METHOD}

Experiment animals. Thirty-two healthy male rabbits nearly of the same age and weighing 950-1050 g were obtained from the animal house, College of Pharmacy, King Saud University. The rabbits were handled and the experiments were conducted in accordance with the protocols approved by the animal bioethical committee at King Saud University.

Sildenafil. Tablets of this drug containing sildenafil citrate equivalent to 50 or $100 \mathrm{mg}$ of sildenafil (Fluka, Switzerland), were utilized in the present work. Sildenafil has optimum $\mathrm{pH}$ at 4.5 , accordingly, the drug was dissolved in sterile normal saline $(0.45 \%$ sodium chloride injection, $\mathrm{pH}$ at (4.354.5 ) at $37^{\circ} \mathrm{C}$ immediately before use. Drug solutions were prepared so that the necessary dose could be administered i.p. in a volume of one ml. The selection of doses and the route of administration were based on data from previous works.

Propolis. Commercial water-soluble propolis crude in the form of capsules (1000 mg) manufactured by Marnys Spanish Company (Spain) and legally imported by Saudi
Arabian Drug Store Ltd. (Saudi Arabia) was used. Its active ingredients were identified by the quality control of the manufacturer to contain the following: Phenolic acids (caffeic acid, tocopherol, sinapic acid, cinamic acid, coumaric acid and ferulic acid) and flavonoids (quercetin, kaempferol, rutin and apigenin) together with amino acids and vitamins.

For the use of propolis in the present work, capsules content, was dissolved immediately before use in sterile distilled water.

Experimental protocol. Rabbits were randomly divided into four groups (eight rabbits each) and were treated for 35 days as follows:

- Group I (control group): Each member of this group received daily intrapertonial (ip) injection of one $\mathrm{ml}$ of sterile $0.45 \%$ sodium chloride together with an oral dose of one $\mathrm{ml}$ of sterile distilled water.

- Group II: Each member of this group received daily ip injection of sildenafil ( $3 \mathrm{mg} / \mathrm{kg}$ ) for 35 days.

- Group III: Each member of this group received daily oral propolis dose $(50 \mathrm{mg} / \mathrm{kg})$ for 35 days.

- Group IV: Each member received daily ip injection of sildenafil $(3 \mathrm{mg} / \mathrm{kg})$ and oral dose of propolis $(50 \mathrm{mg} / \mathrm{kg})$ for 35 days.

Morphometric observation. Daily observation throughout the study was made for mortality, general well-being and behavior patterns of all animals under study.

Body weight monitoring. The rabbits body weight was monitored at the beginning of treatment and at the interval of 7 days for 35 days of treatment.

Testis weight monitoring. The rabbits were euthanatized by pentabarbital anesthesia and the testes of each dissected rabbit were removed carefully and weighed in grams. The relative testis weight for each rabbit was calculated according to the following equation:

Relative organ weight $=[$ Absolute testis weight $(\mathrm{g}) /$ Body weight of rabbit (g)] x 100

Testis index. From the obtained data, the amount of change on the relative ratio and the index of the testis (Tx) of rabbits were calculated according to the following equation:

Tx $=$ Average weight of the experimental testis/ Average weight of the experimental animals.

Weight of the control testis/ Average weight of the control animals. 


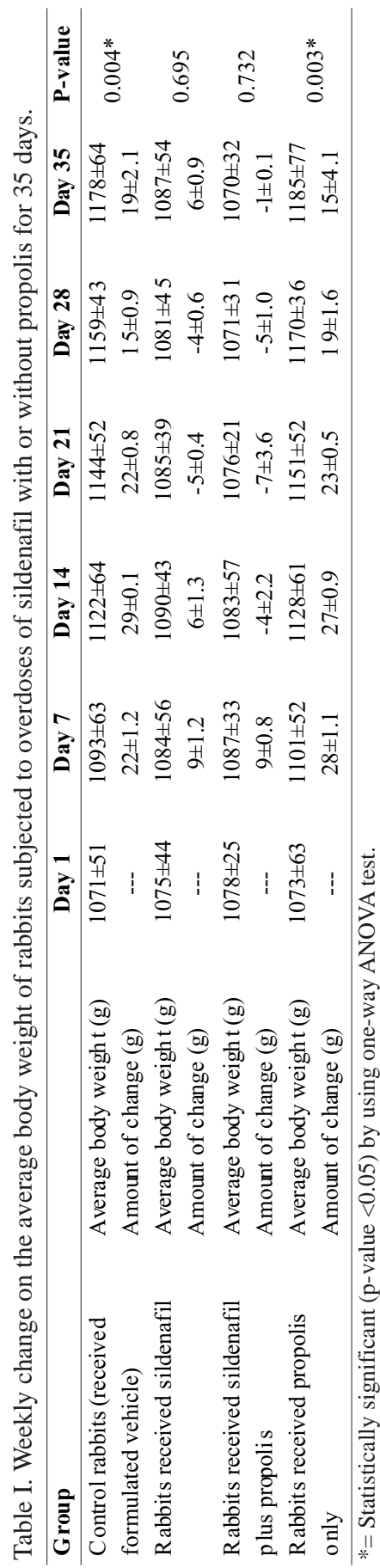

Hormonal analysis. Two days after the final treatment, blood samples were collected from all rabbits under study. Serum was separated by centrifugation and analyzed for testosterone, follicular stimulating hormone and luteinizing hormone. Statistical analysis was done by using independent T-test and the results were expressed by the average \pm SD.

Histological processing. Two days after the final treatment, members of all groups of rabbits were euthanized after 4 weeks of sildenafil administration. Fresh portions of the testes from each rabbit were cut rapidly, fixed in neutral buffered formalin (10\%), then dehydrated, with ascending concentration of ethanol (70, 80, 90, 95 and 2 changes absolute ethanol). Dehydration was followed by clearing the samples in 2 changes of xylene and then were then impregnated with 2 changes of molten paraffin wax, embedded and blocked out. Paraffin sections (4-5 $\mathrm{mm}$ ) were stained with hematoxylin and eosin, Mallory trichrome and periodic acid-Schif (PAS) stains. Stained sections of the control and treated testes sections of all treated rabbits were examined for alterations in the testicular tissues.

Statistical analysis. Statistical analysis was done by using independent t-test and the results of the morphometric and biochemical analysis were expressed by the average \pm SD. The p-value $<0.05$ was considered statistically significant.

\section{RESULTS}

Morphometric alterations. While no mortality was demonstrated, testicular varicose together with testes enlargement and spermatic cord dilatation in the rabbits exposed to sildenafil were seen (Fig. 1). These alterations were less prominent in rabbits received sildenafil plus propolis.

Body weight variation. After 35 days of sildenafil administration, variation of the body weight during drug exposure is given in Table I. It is observed that sildenafil

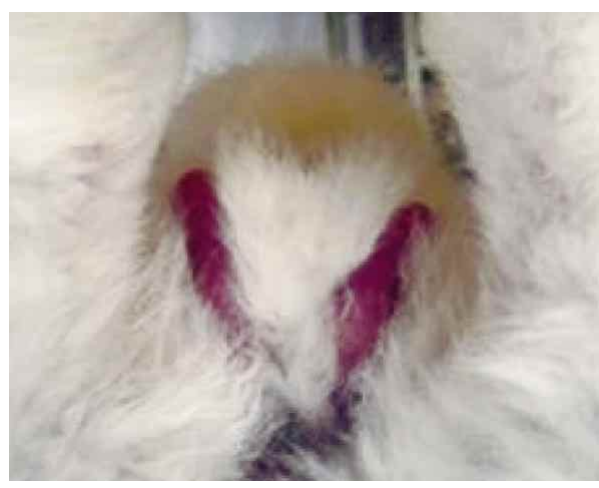

Fig. 1. Light photograph demonstrating testes enlargement and congestion in rabbits that received sildenafil for 35 days.

Table II. Alteration on the relative weight and index of testis of rabbits with or without propolis for 35 days.

\begin{tabular}{lcccc}
\hline Group & $\begin{array}{c}\text { Average total } \\
\text { testis weight(g) }\end{array}$ & $\begin{array}{c}\text { Average body } \\
\text { weight }(\mathbf{g})\end{array}$ & $\begin{array}{c}\text { Relative tes tis } \\
\text { weight }\end{array}$ & $\begin{array}{c}\text { Testis } \\
\text { index (T) }\end{array}$ \\
\hline $\begin{array}{l}\text { Control rabbits } \\
\text { (received formulated vehicle) }\end{array}$ & $1.035 \pm 0.18$ & $1178 \pm 64$ & $0.00087 \pm 0.0003$ & 1.0 \\
Rabbits received sildenafil & $1.093 \pm 0.15$ & $1087 \pm 54$ & $0.001 \pm 0.0005$ & $1.15^{*}$ \\
Rabbits received sildenafil plus propolis & $1.052 \pm 0.23$ & $1070 \pm 32$ & $0.00098 \pm 0.0002$ & $1.12^{*}$ \\
Rabbits received propolis only & $1.047 \pm 0.15$ & $1185 \pm 77$ & $0.00088 \pm 0.0003$ & 1.01 \\
\hline
\end{tabular}

$*=$ Statistically significant $(\mathrm{p}$-value $<0.05$ ) by using $\mathrm{t}$-student test. 
administration decreased significantly the body weight gain, while sildenafil plus propolis administration could not ameliorate this alteration. In addition, propolis administration only showed similar influence on the body weight gain ( $p$ value $<0.05$ ) to that seen by the control group.

Alteration on testes morphology. As seen in Table II, rabbits treated with sildenafil showed significant ( $p$ value $<0.05$ ) increased ratios of total testis weight to body weight together with an increase of the testis index. Administration of propolis plus sildenafil did not ameliorate this effect.

Hormonal alterations. As seen in Table III, sildenafil overdosing for 4 weeks lowered testosterone and follicular stimulating hormone while luteinizing hormone level was not altered significantly. In comparison with the control rabbits, little hormonal alteration was demonstrated by rabbits subjected to both sildenafil and propolis.

\section{Histological alterations}

Control rabbits. As seen in Figures 2 and 3, the control rabbits showed normal histological structures of the seminiferous tubules together with normal spermatogenic cells and normal interstitial tissues.

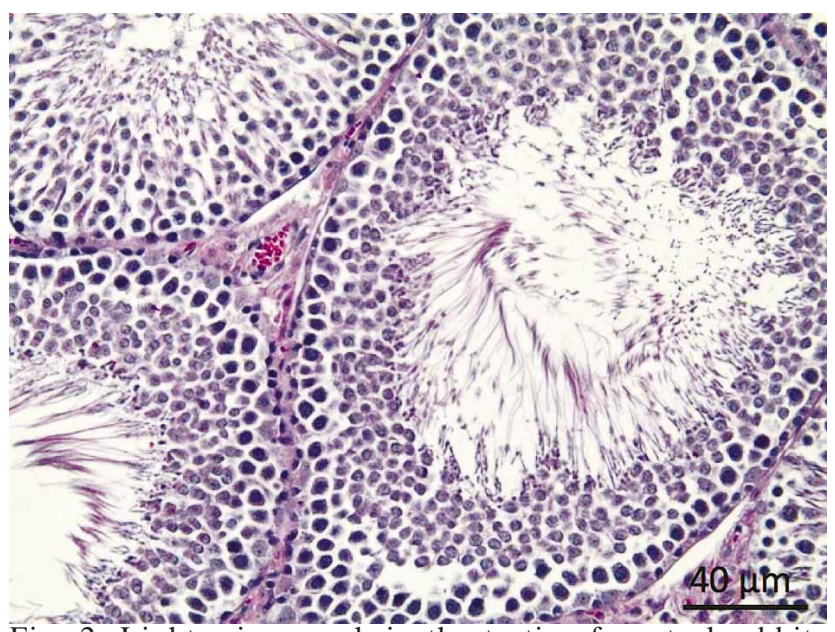

Fig. 2. Light micrograph in the testis of control rabbits demonstrating normal seminiferous tubules. Mallory trichrome stain.
Sildenafil treated rabbits. In comparison with the control group, the following histological alterations were detected in the testicular tissues of rabbits exposed to sildenafil (3 $\mathrm{mg} / \mathrm{kg}$ ) for 4 weeks, 5 days each week.

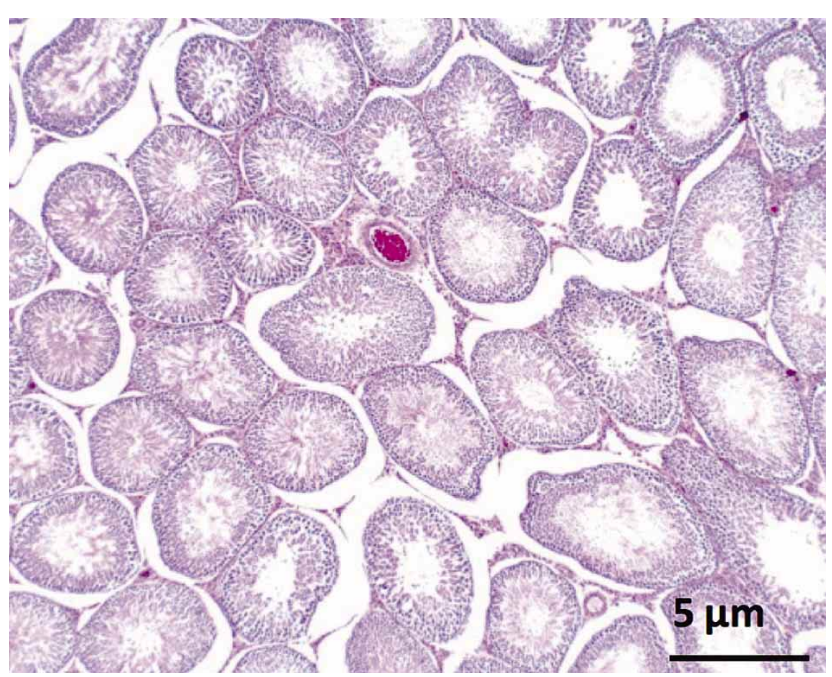

Fig. 3. Light micrograph in the testis of control rabbits demonstrating normal spermatogenesis process. H\&E stain.

Seminiferous tubules degeneration. Considerable seminiferous tubules epithelial lining degeneration of the sildenafil treated rabbits was observed (Fig. 4). Some seminiferous tubules exhibited ghost appearance in a completely reabsorbed disorganized form (Fig. 5). In addition, seminiferous tubules widening was also recognized in the testicular tissues of all rabbits subjected to sildenafil $(3 \mathrm{mg} / \mathrm{kg})$ for 4 weeks.

Spermatocytes nuclear alterations. Subjection to sildenafil for four weeks induced spermatocytes karyopyknosis. This alteration was almost demonstrated by spermatocytes of the seminiferous tubules that exhibited necrosis (Fig. 6).

Spermatocytes sloughing. Desquamation and sloughing of spermatocytes were also observed in the lumens of the some tubules of intoxicated rabbits (Fig. 7). Spermatids, cellular debris together with occasional spermatid giant cells were also observed.

Spermatogenesis arrest. As seen in Figure 8, some

Table III. Hormonal biochemical alterations of rabbits subjected to overdoses of sildenafil with or without propolis for 35 days.

\begin{tabular}{lccc}
\hline Group & $\begin{array}{c}\text { Testosterone } \\
(\mathbf{n m o l} / \mathbf{l})\end{array}$ & FSH (IU/I) & $\begin{array}{c}\text { Luteinizing } \\
\text { h ormone (IH/l) }\end{array}$ \\
\hline Control rabbits (received formulated vehicle) & $5.9 \pm 0.7$ & $2.3 \pm 0.2$ & $2.9 \pm 0.6$ \\
Rabbits received sildenafil & $4.3 \pm 0.2$ & $1.8 \pm 0.4$ & $2.8 \pm 0.1$ \\
Rabbits received sildenafil plus propolis & $6.2 \pm 0.5$ & $2.1 \pm 0.1$ & $3.1 \pm 0.2$ \\
Rabbits received propolis only & $5.6 \pm 0.1$ & $1.9 \pm 0.5$ & $3.0 \pm 0.3$ \\
\hline
\end{tabular}




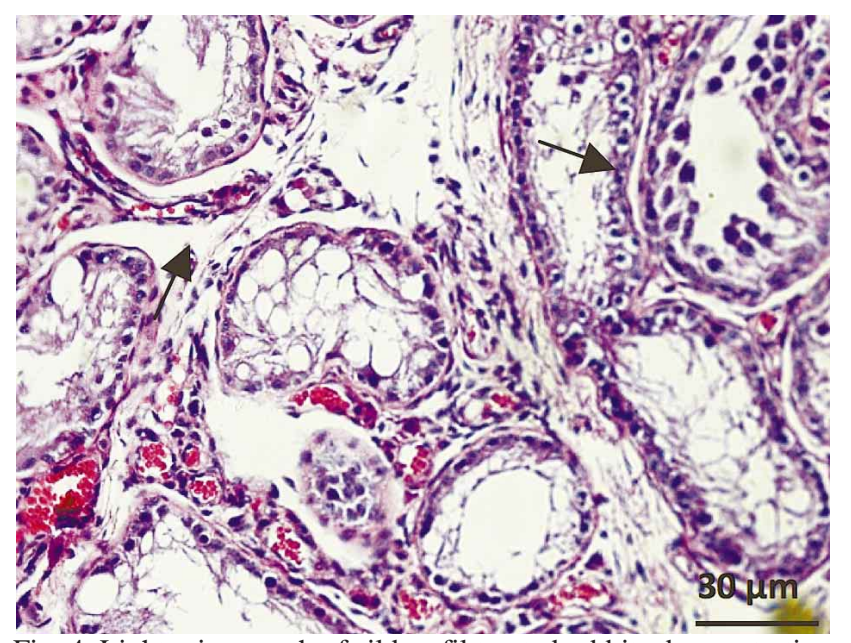

Fig. 4. Light micrograph of sildenafil treated rabbits demonstrating degenerative seminiferous tubules (arrows). Mallory trichrome stain.

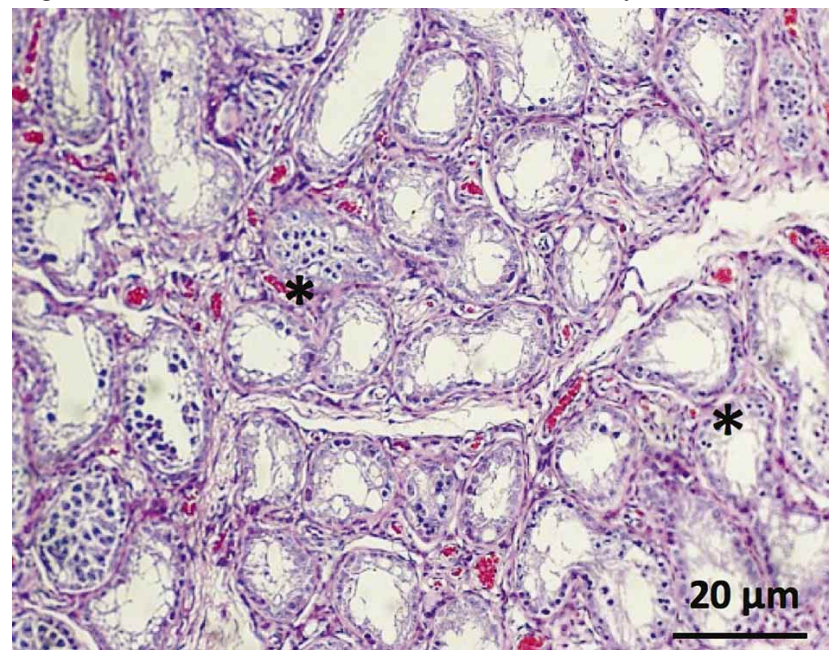

Fig. 5. Light micrograph of sildenafil treated rabbits demonstrating reabsorbed disorganized seminiferous tubules (stars). H\&E stain.

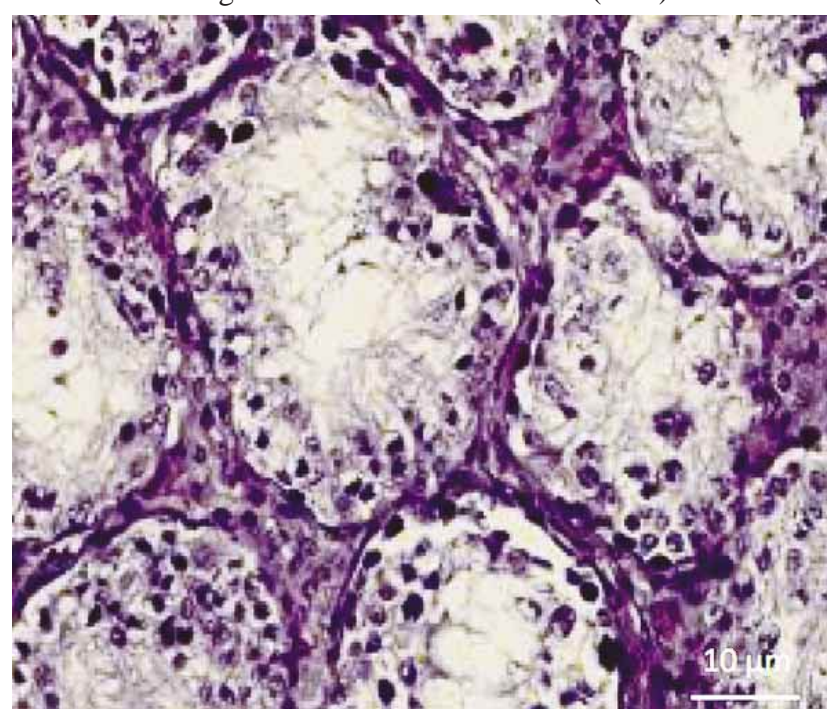

Fig. 6. Light micrograph of sildenafil treated rabbit showing spermatocytes karyopykonosis. H\&E stain. seminiferous tubules of this group of rabbits exhibited low number of spermatozoa in their lumens in comparison with control ones. Some tubules demonstrated this damage at the primary spermatocytes stage.

In addition, corrugated and thickened seminiferous tubules basement membranes together with interstitial tissue proliferation were also demonstrated by the testes of all rabbits subjected to sildemafil. Occasional interstitial endocrine cells hyperplasia together with intertubular blood vessels congestion were also detected.

Rabbits exposed to sildenafil and propolis. As seen in Figure 9 , the testis of rabbits receiving sildenafil $(3 \mathrm{mg} / \mathrm{kg})$ plus propolis $(50 \mathrm{mg} / \mathrm{kg})$ showed almost normal histological pictures with normal spermatogenesis process. Neither

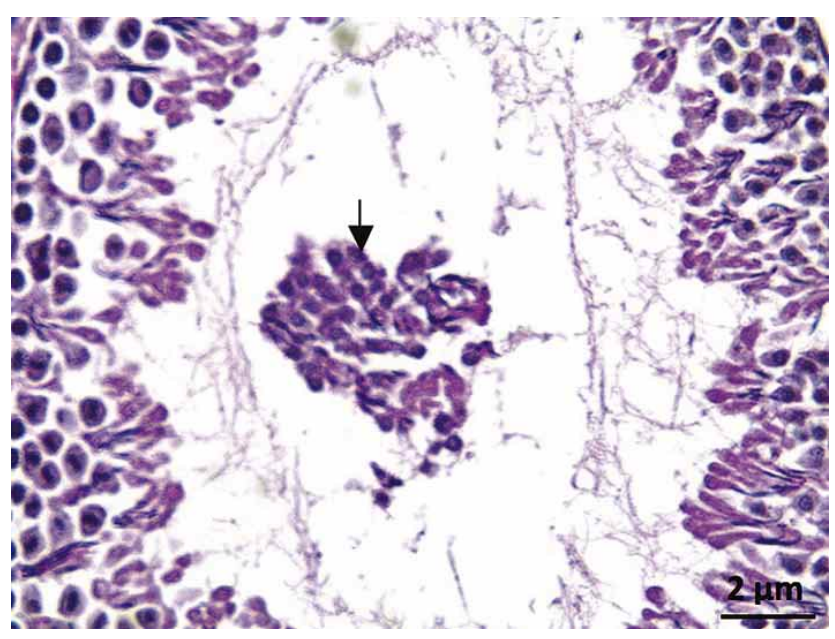

Fig. 7. Light micrograph of sildenafil treated rabbit demonstrating spermatocytes sloughing (arrow). H\&E stain.

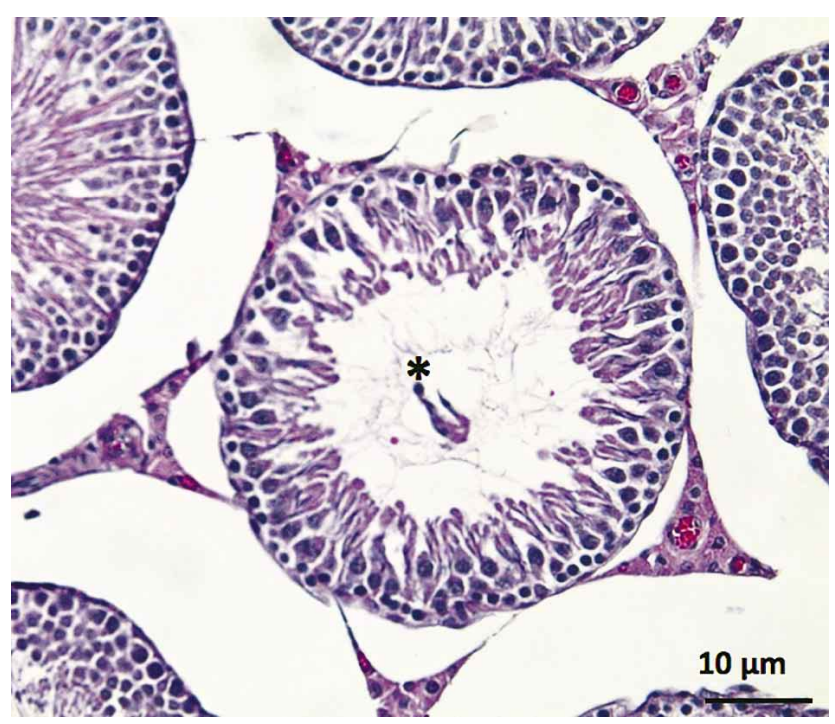

Fig. 8. Light micrograph of sildenafil treated rabbit demonstrating oligozoospermia (star). H\&E stain. 
tubular degeneration nor spermatocytes sloughing was demonstrated in this group of rabbits. Moreover, little spermatocytes morphological nuclear alterations were seen while Leydig cells restore their normal structure.

Rabbits treated with propolis only. Animals of this group presented neither tubular alterations nor spermatogenesis disturbances (Fig. 10).

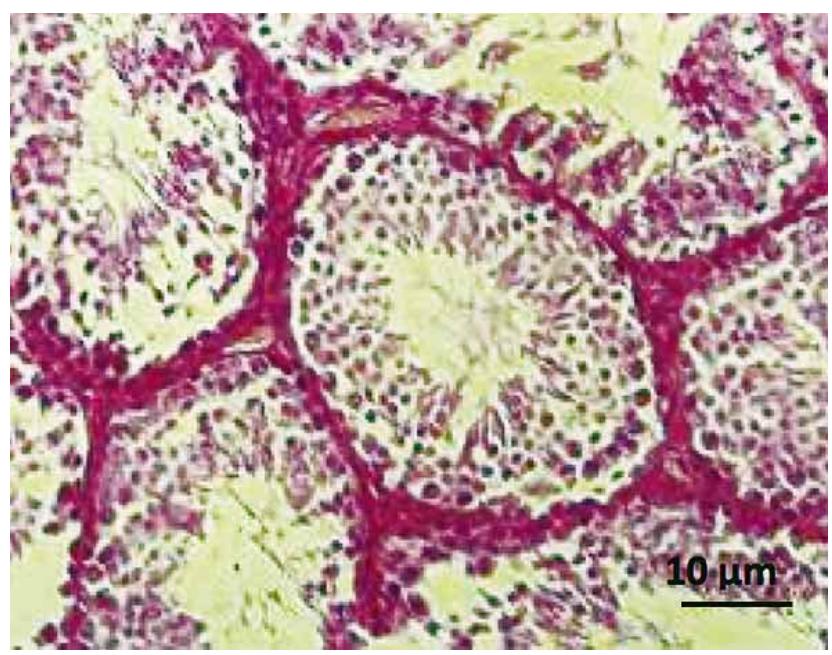

Fig. 9. Light micrograph of rabbit testicular tissue receiving both sildenafil plus propolis showing normal seminiferous tubules and normal intertubular tissues. H\&E stain.

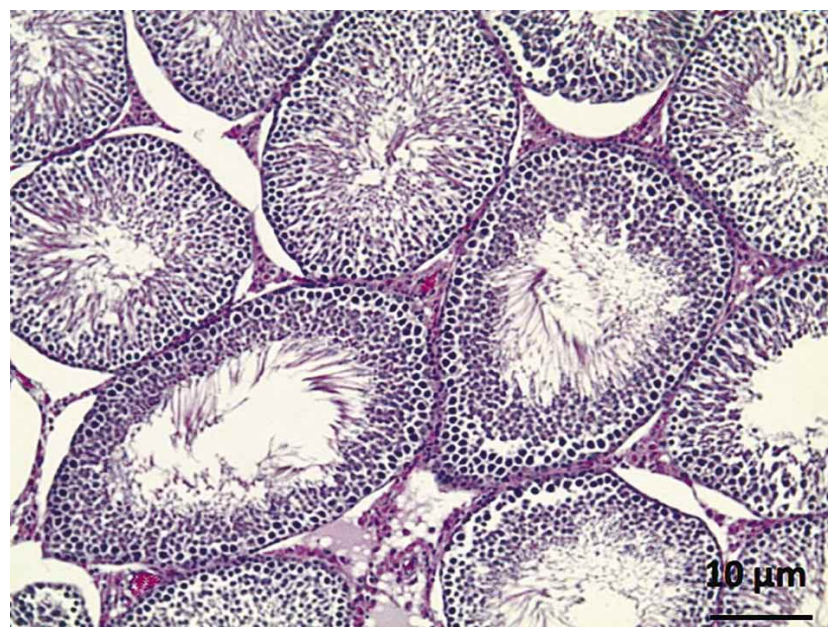

Fig. 10. Light micrograph of rabbit testicular tissue received propolis showing normal testicular tissue. H\&E stain.

\section{DISCUSSION}

Sildenafil overdoses uptake is mainly seen among men suffer from erectile dysfunction where the stigma of this disease surrounds them and their partners. In addition, sildenafil popularity is increasing with young adults due to the belief that the drug increases libido, improves sexual performance and increases penis size. On the other hand, sildenafil overdose fatality death among men with potential arrhythmia is on the rise and have reached crisis levels in certain countries (Tracqui et al.).

Organ weight is one of the most sensitive indicator of toxic agents that reflect the impact on the body metabolism and on immunological status of the body. The results of the present work showed that exposure to sildenafil decreased body weight gain and increased the testis index more than the members of the control rabbits and those receiving sildenafil and propolis. This alteration might result from the toxicity and oxidative stress induced by sildenafil on the body metabolism. On the other hand, the increase in the testis index might be related to testicular congestion induced by sildenafil that could not be ameliorated by propolis.

The results of the present investigation showed that sildenafil exposure lowered testosterone level and caused tubular degeneration together with spermatogenic arrest. These alterations might indicate susceptibility of the seminiferous epithelium to sildenafil toxicity with possible consequences on the intercellular junction between the strata of the germinal cells. Some histological findings are in agreement with those reported by Jarrar (2011).

Spermatids sloughing as demonstrated by the present work might indicate that sildenafil could induce cytotoxicity. The detachment of these testicular cells might be resulted from the disruption of physical interaction of these cells due to sildenafil toxicity. In addition, the observed detachment of spermatocytes might be related to decline in testosterone level. Spermatocytes cytoskeleton is testosterone dependent where the junction between spermatogenic cells is dispersed in the absence or low concentration of testosterone (Lee et al., 1999). Accordingly, the results of the present work might indicate that sildenafil toxicity could alter spermatocytes cytoskeleton preventing spermatocyte to differentiate to spermatozoon leading to spermatogenic arrest as an end product. Spermatogenesis depends precisely on spermatogonial cell differentiation, and cell-cell interactions of germ cells with Sustentocyte (Sertoli cells) (Matsumiya et al., 2013).

Seminiferous tubules degeneration might indicate sildenafil interference in the dynamic process of spermatogenesis. The results of the present work might indicate that propolis could protect the testicular tissues from seminiferous tubules damage and spermatogenesis disturbances induced by sildenafil. This protective role might be attributed to propolis flavonoids content which is capable 
of scavenging free radicals and prevents lipid peroxidation (Yousef \& Salama; Guimarães et al., 2012). Cellular components are susceptible to damage by free radicals via lipids peroxidation and proteins denaturation respectively, thus leading to organelles deterioration (Bergamini et al., 2004).

Propolis was evaluated against several chemicals, environmental toxicants and drugs. Yousef \& Salama reported a protective effect to propolis against aluminum chloride reproductive toxicity by inhibiting free radical formation due to its free radical scavenging ability. This crude can also activate superoxide dismutase and catalase that have capability against free radicals (Jasprica et al., 2007). Moreover, some previous studies reported that the phenolic contents of propolis could inhibit membrane free radical formation and have the capability to protect the mitochondria and cellular macromolecules against oxidative damage (Kanbur et al., 2009).

\section{CONCLUSION}

One may conclude from the findings of the present work that propolis has the potential to protect partially the testicular tissues from possible consequences on fertility and reproduction induced by sildenafil overdoses. This protective role might be related to the antioxidants content of propolis by compacting free radicals and oxidative stress induced by sildenafil overdoses. More studies are needed to investigate the adverse effect of these doses on the other vital organs.

\section{ACKNOWLEDGEMENTS}

The authors would like to extend their sincere appreciation to the Deanship of Scientific Research at King Saud University for its funding this research group (RG1435-040).

ALMANSOUR, M.; JARRAR, Y. \& JARRAR, B. Rol protector del propóleo contra las alteraciones morfológicas, hormonales, bioquímicas e histológicas inducidas por sobredosis de sildenafil. Int. J. Morphol., 34(2):533-540, 2016.

RESUMEN: El sildenafil es un medicamento ampliamente utilizado para el tratamiento de la disfunción eréctil y existen pocos estudios disponibles referente a la función protectora del propóleo contra su toxicidad reproductiva. El objetivo fue investigar las alteraciones hormonales, bioquímicas e histomorfométricas, inducidas en los tejidos testiculares por sobredosis de sildenafil. Cuatro grupos de conejos fueron expuestos a sildenafil con o sin propóleo de la siguiente manera: grupo I recibió el sildenafil formulado, grupo II recibió sildenafil (3 mg/kg), grupo III recibió propóleo $(50 \mathrm{mg} / \mathrm{kg}$ ) y el grupo IV recibió sildenafil más propóleo. El sildenafil redujo el peso corporal, la testosterona y la concentración de la hormona foliculoestimulante, sin embargo, se observó un aumento del índice testicular mientras que la hormona luteinizante casi no se vio afectada. Por otra parte, los conejos tratados con sildenafil mostraron degeneración de los túbulos seminíferos, trastornos de la espermatogénesis y alteraciones nucleares de los espermatocitos. Con el uso de sildenafil más propóleo fue posible disminuir las alteraciones de los túbulos seminíferos, los trastornos de la espermatogénesis y los niveles de cambios hormonales; los espermatocitos fueron protegidos parcialmente de alteraciones nucleares morfológicas, pero no pudo mejorar el efecto de aumento de peso corporal e índice testicular. Los resultados indican que el propóleo puede aliviar, en parte, la toxicidad en la reproducción inducida por sobredosis de sildenafil. No obstante, existe la necesidad de realizar más estudios sobre los efectos adversos de estas dosis en otros órganos vitales.

PALABRAS CLAVE: Propóleo; Sildenafil; Testículos; Alteraciones histológicas; Toxicidad.

\section{REFERENCES}

Abdülkadir Coban, T.; Beydemir, S.; Gülcin, I.; Ekinci, D.; Innocenti, A.; Vullo, D. \& Supuran, C. T. Sildenafil is a strong activator of mammalian carbonic anhydrase isoforms I-XIV. Bioorg. Med. Chem., 17(16):5791-5, 2009.

Badr, M. O. T.; Edrees, N. M. M.; Abdallah, A. A. M.; Hashem, M. A.; El-Deen, N. A. M. N.; Neamat-Allah, A. N. F. \& Ismail, H. T. H. Propolis protects against methotrexate induced hepatorenal dysfunctions during treatment of Ehrlich carcinoma. J. Am. Sci., 7(12):313-9, 2011.
Bergamini, C. M.; Gambetti, S.; Dondi, A. \& Cervellati, C. Oxygen, reactive oxygen species and tissue damage. Curr. Pharm. Des., 10(14):1611-26, 2004.

Boolell, M.; Allen, M. J.; Ballard, S. A.; Gepi-Attee, S.; Muirhead, G. J.; Naylor, A. M.; Osterloh, I. H. \& Gingell, C. Sildenafil: an orally active type 5 cyclic GMP-specific phosphodiesterase inhibitor for the treatment of penile erectile dysfunction. Int J. Impot. Res., 8(2):47-52, 1996. 
El-Mazoudy, R. H.; Attia, A. A. \& El-Shenawy, N. S. Protective role of propolis against reproductive toxicity of chlorpyrifos in male rats. Pestic. Biochem. Physiol., 101(3):175-81, 2011.

Guimarães, N. S.; Mello, J. C.; Paiva, J. S.; Bueno, P. C.; Berretta, A. A.; Torquato, R. J.; Nantes, I. L. \& Rodrigues, T. Baccharis dracunculifolia, the main source of green propolis, exhibits potent antioxidant activity and prevents oxidative mitochondrial damage. Food Chem. Toxicol., 50(3-4):1091-7, 2012.

Huddleston, A. J.; Knoderer, C. A.; Morris, J. L. \& Ebenroth, E. S. Sildenafil for the treatment of pulmonary hypertension in pediatric patients. Pediatr. Cardiol., 30(7):871-82, 2009.

Jarrar, B. M. Histological alterations in the testicular tissue induced by sildenafil overdoses. Drug Metab. Lett., 5(2):99-103, 2011.

Jasprica, I.; Mornar, A.; Debeljak, Z.; Smolcic-Bubalo, A.; MedicSaric, M.; Mayer, L.; Romic, Z.; Bucan, K.; Balog, T.; Sobocanec, S. \& Sverko, V. In vivo study of propolis supplementation effects on antioxidative status and red blood cells. J. Ethnopharmacol., 110(3):548-54, 2007.

Kanbur, M.; Eraslan, G. \& Silici, S. Antioxidant effect of propolis against exposure to propetamphos in rats. Ecotoxicol. Environ. Saf., 72(3):909-15, 2009.

Khalil, M. L. Biological activity of bee propolis in health and disease. Asian Pac. J. Cancer Prev., 7(1):22-31, 2006.

Krenzelok, E. P. Sildenafil: clinical toxicology profile. J. Toxicol. Clin. Toxicol., 38(6):645-51, 2000.

Lee, J.; Rhichburg, J. H.; Shipp, E. B.; Meistrich, M. L. \& Boekelheide, K. The Fas system, a regulator of testicular germ cell apoptosis, is differentially up-regulated in Sertoli cell versus germ cell injury of the testis. Endocrinology, 140(2):8528, 1999.

Lejeune, B.; Pourrat, A. \& Dehmouche, H. Propolis use in dermatocosmetology. Parfum. Cosmet. Aromes, 82:73-7, 1988.

Matsumiya, K.; Meistrich, M. L.; Shetty, G.; Dohmae, K.; Tohda, A.; Okuyama, A. \& Nishimune, Y. Stimulation of spermatogonial differentiation in juvenile spermatogonial depletion (jsd) mutant mice by gonadotropin-releasing hormone antagonist treatment. Endocrinology, 140(10):49125, 2013.

Müller, A.; Smith, L.; Parker, M. \& Mulhall, J. P. Analysis of the efficacy and safety of sildenafil citrate in the geriatric population. B. J. U. Int., 100 (1):117-21, 2007.

Oruc, O.; Inci, K.; Aki, F. T.; Zeybek, D.; Muftuoglu, S. F.; Kilinc, K. \& Ergen, A. Sildenafil attenuates renal ischemia reperfusion injury by decreasing leukocyte infiltration. Acta Histochem., 112(4):337-44, 2010.
Saraiva, K. L.; Silva, A. K.; Wanderley, M. I.; De Araújo, A. A.; De Souza, J. R. \& Peixoto, C. A. Chronic treatment with sildenafil stimulates Leydig cell and testosterone secretion. Int. J. Exp. Pathol., 90(4):454-62, 2009.

Schultheiss, D.; Stief, C. G.; Truss, M. C. \& Jonas, U. Pharmacological therapy in erectile dysfunction--current standards and new viewpoint. Wien. Med. Wochenschr., 147(45):102-4, 1997

Sergeant, G. P.; Craven, M.; Hollywood, M. A.; McHale, N. G \& Thornbury, K. D. Spontaneous $\mathrm{Ca}^{2+}$ waves in rabbit corpus cavernosum: modulation by nitric oxide and cGMP. J. Sex Med., 6(4):958-66, 2009.

Tracqui, A.; Miras, A.; Tabib, A.; Raul, J. S.; Ludes, B. \& Malicier, D. Fatal overdosage with sildenafil citrate (Viagra): first report and review of the literature. Hum. Exp. Toxicol., 21(11):6239, 2002.

Urgur, A. \& Arslan, T. An in vitro study on antimicrobial activity of propolis from Mugla province of Turkey. J. Med. Food, 7(1):90-4, 2004.

Wang, C. Phosphodiesterase-5 inhibitors and benign prostatic hyperplasia. Curr. Opin. Urol., 20(1):49-54, 2010.

Yousef, M. I. \& Salama, A. F. Propolis protection from reproductive toxicity caused by aluminium chloride in male rats. Food Chem. Toxicol., 47(6):1168-75, 2009.

Yousef, M. I.; Kamel, K. I.; Hassan, M. S. \& El-Morsy, A. M. Protective role of propolis against reproductive toxicity of triphenyltin in male rabbits. Food Chem. Toxicol., 48(7):1846$52,2010$.

Correspondence to:

Prof. Bashir M. Jarrar

Department of Biological Sciences

College of Science

Jerash University

Jerash

JORDAN

Email: bashirjarrar@yahoo.com

Received: 30-11-2015

Accepted: 25-02-2016 